\title{
Study and comparison of image developments in Persian poetry (from classical to contemporary)
}

\section{Estudio y comparación de la evolución de la imagen en la poesía persa (desde la clásica hasta la contemporánea)}

\author{
Mohammad Shah Badizadeh \\ Member of the Department of Persian Language and Literature, Islamic Azad University, \\ Mashhad Branch, Iran \\ Javad Mehraban \\ Member of the Department of Persian Language and Literature, Islamic Azad University, \\ Mashhad Branch, Iran \\ Leila Kabari Ghotbi
}

PhD Student in Persian Language and Literature, Islamic Azad University, Mashhad Branch, Iran

Received 07-08-20 Revised 08-10-20

*Correspondence

Email: LeilaKabariGhotbi@gmail.com
Accepted 09-02-20 On line 03-07-21

Cite as:

Badizadeh, M., Mehraban, J., \& Ghotbi, L. (2021). Study and comparison of image developments in Persian poetry (from classical to contemporary). Propósitos y

Representaciones, 9(SPE3), e1109.

http://dx.doi.org/10.20511/pyr2021.v9nSPE3.1109 


\begin{abstract}
In any literary style or period, there are always common factors and contexts between poets and writers that make up the color and public space of that period. One of these contexts are elements and themes that are used in poetic images; Elements such as nature, ordinary and peripheral elements, literary subtleties in image making, etc. are the themes that can lead us to obvious differences between the illustrations of each period in each period and can finally be a basis for evaluation. The artistic and imaginative values and features of each period become and lead us to the important point that the image is a representation of sensory effect in language. This sensory effect also includes: the poet's thoughts, feelings and sensory experiences. The importance of illustration and illustration is such that, in the opinion of many, any change in the illustration of the world also leads to a change in the mechanism of the world. What constitutes the basis of the present research is the study and study of the illustration processes of old and new Persian poetry in two ways, method and subject of the image. The results of the present study show that although the overall image structure of Persian poetry from ancient times to modern times has been based on one principle, but the subject of these images is different in two periods so that the image in ancient poetry is based on "nature and imagination". While the basis of the image in contemporary poetry is "man and society".
\end{abstract}

Keywords: image, image elements, ancient poetry, contemporary poetry, image subject.

\title{
Resumen
}

En cualquier estilo o época literaria, siempre existen factores y contextos comunes entre poetas y escritores que configuran el color y el espacio público de esa época. Uno de estos contextos son elementos y temas que se utilizan en imágenes poéticas; Elementos como la naturaleza, elementos ordinarios y periféricos, sutilezas literarias en la creación de imágenes, etc. son los temas que pueden llevarnos a diferencias obvias entre las ilustraciones de cada período en cada período y finalmente pueden ser una base para la evaluación. Los valores y rasgos artísticos e imaginativos de cada período se convierten y nos llevan al punto importante de que la imagen es una representación del efecto sensorial en el lenguaje. Este efecto sensorial también incluye: los pensamientos, sentimientos y experiencias sensoriales del poeta. La importancia de la ilustración y la ilustración es tal que, en opinión de muchos, cualquier cambio en la ilustración del mundo también conduce a un cambio en el mecanismo del mundo. Lo que constituye la base de la presente investigación es el estudio y estudio de los procesos de ilustración de la poesía persa antigua y nueva de dos formas, método y tema de la imagen. Los resultados del presente estudio muestran que aunque la estructura general de la imagen de la poesía persa desde la antigüedad hasta la época moderna se ha basado en un principio, el tema de estas imágenes es diferente en dos períodos, por lo que la imagen en la poesía antigua se basa en "naturaleza e imaginación". Mientras que la base de la imagen en la poesía contemporánea es "el hombre y la sociedad".

Palabras clave: imagen, elementos de la imagen, poesía antigua, poesía contemporánea, sujeto de la imagen.

Introduction and problem statement

(Image) has been translated into Persian as "Imagination" and "Imaginary Image". The equivalent of "imagination" has become more popular in Persian. The term refers to a collection of poetic images and the entire virtual language; Namely: that part of the creative and artistic uses of language that arises through the possessions of imagination in ordinary language (Fotouhi, 1381: 17). "In Persian literature, image refers to imaginary forms, that is, an image in which industries such as simile and metaphor have been used and the image is often considered specific to poetry." (Khozan, 1374: 75).

In the study of literature, images are divided into two categories: the image obtained by the mental embodiment of words in their lexical sense, and images created by the relationship 
between two or several seemingly different objects. In other words, these two or more objects and their images are connected in the mind through poetic imagination and emotion. The third thing does not exist in the virtual image in the real world, but is itself a new form of reality. The capture of the imagination in natural affairs is the same as the imaginative image that encompasses the various talents of the mind, including: emotion, consciousness, and human imagination. In fact, every imaginary image is the result of the emotion and mental experience of the poet or writer and a means of transmitting this experience to others. The poet or writer's mind, with the help of the power of imagination, discovers new connections between man and nature and the objects around them, and this discovery is transmitted to the reader by imaginary images, created by his mind and the result of his imagination in the concepts of life. Mirsadeghi, 1997: Below the picture).

Imagination is considered by many to be the main essence of poetry and in many definitions of poetry is one of the pillars of definitions (ibid.). It is imaginary (Shamisa, 1997: 85).

Every poet tries to spice up his poetry with artistic images. "A poem without an image is not considered a poem" (Yousefi, 1361: 113); But the attractiveness and attractiveness of these images and the success or failure of the poet in presenting his poetic images is something that goes back to the extent of the use of illustrators in each poem. As in a painting, the artistic use and correct combination of colors along with the techniques of this art, adds to the importance of the work and its value. The use of illustrative elements based on the rhetorical levels of imagination in poetry and the poet's ability to use these elements correctly and persuasively, is effective in creating his literary and artistic images and as a result the effectiveness of his poetry. Illustration in Persian poetry from ancient times to modern times is based on rhetorical subtleties such as: simile, metaphor, metaphor, irony, etc., and the process of new studies (like the rhetorical picture book written by Dr. Mahmoud Fotouhi) division Other words such as: linguistic image, surface image, composite image, imaginary image, etc., which are specific to the two periods of Persian poetry, and examples of them can be seen abundantly in the poetry of the two periods, Now, in this research, we intend to examine the process of illustration developments in classical and contemporary Persian poetry, so the main question that constitutes the body of the present study is that the illustration developments in classical and contemporary poetry and What have changed in contemporary Persian as well as the subject of illustration?

The present study, in a descriptive-analytical manner and relying on the library method, intends to study the process of illustration in Persian poetry (from classical to contemporary) in two areas of method and subject.

\section{background research}

In the field of poetic images in general and images of contemporary poetry in particular, research has been done and in the following some of the most important of themQol is analyzed from the overall structure of the poem. This is due to the attitude that industry in the service of meaning and image (image) is a function of poetic thought and plays the role of serving the meaning. Literary crafts are tools for explanation and expression and clothing for embellishing meaning, so they have two basic tasks.

1) Explain and emphasize the meaning and its explanation and fixation

2) Makeup and decoration of meaning (Rak, Fotouhi, 1384: 25).

1) Explanation, emphasis and explanation of meaning

The first task, that is, to explain and emphasize the meaning and spirit and to establish it, is completely related to the principles of classical art. Artistic expression must be completely clear, convincing the intellect, and emphasizing fixed and permanent values. Therefore, metaphor, simile, irony and other poetic crafts should be in the service of meaning, add to the 
authority of meaning, put on a new garment on its stature, and help to explain and expand the idea and establish it in the mind and conscience of the listener. The task of the image is enlightenment and the power of appearance and exaggeration in meaning. Among the images of ancient poetry, similes and allegories are the most widely used, because they are highly effective in explaining and explaining thought. In the poetry of the first period of Dari Persian in the Samanid and Ghaznavid eras, simile is the dominant element. Because simile is the most appropriate method for a purpose that requires a traditional mind and attitude from poetry and poetic image. That is, the image has the function of explaining and interpreting poetic thought and experience. Simile is the best tool for expressing imitations and imitating nature and exponentiality. (Same: 25 )

In this verse of Farrokhi Sistani (429 AH) the power and effect of the word is the result of simile:

Until the red cups of Mel came out of the flower horns, the people's hands clasped their heads from the sycamore

(Farrokhi Sistani, 1375: 49)

The likeness of the sycamore leaf to the hands of the people is the basis of the beauty and influence of Beit Farokhi.

It is also in the following verse from Manouchehri Damghani:

Nobahar came and brought flowers and jasmine garden like Tibet and Ragh like Adna

The sky made a tent from Bayram and Diba Kaboud nailed the tent of Stack Seman and Nastarna

(Manouchehri, 79: 1371)

2) Meaningful decoration and decoration

Another function of the image in ancient Persian poetry is "arrangement and decoration of meaning". Relying on the tools of the image, the poet seeks makeup as well as giving meaning to his poetry. For example, in the following verse from Farrokhi Sistani, we see the arrangement and decoration of meaning:

Cloudy outcrop on the blue sea Chou Rai Asheghan Gardan Cho Bidlan Sheida

He went back and forth, sometimes dark, sometimes bright, and sometimes he found the sky and sometimes the sun did not disappear

Farrokhi Sistani, 1375: 68)

It is also in the following verse from Ferdowsi's Shahnameh:

A night like the night on the washed Baqir, neither Mars nor Saturn nor Mercury

A different kind of Kurdish make-up

(Ferdowsi, 58: 1387)

As it follows from the above verses, the poet of ancient Persian poetry uses the image in two modes of "explanation and emphasis as well as decoration of meaning" (Fotouhi, 1384: 26).

Theoretical foundations of imagery in ancient poetry 
Illustration is the result of the kind of cognition and the kind of poetic experience. Nietzsche makes a beautiful statement in this regard: "Ultimately, man sees nothing in objects but what he has given them." The traditionalist view sees the world as based on its own mentality and depicts the same views. Ancient poets perceive the world only with material sense and value and value this perception, so the creation of the image of imagination in their art is based on at least four bases.

A) Sensory knowledge: The image of traditional poetry is the product of sensory cognition and knowledge.

B) Description of experience: The poet's work is a clear description of this sensory experience.

C) Direct Imagination: Objects are depicted directly and directly.

D) Absolute beauty (Rak, Fotouhi, 1384: 31-32).

We now turn to each of these principles.

\section{Sensory knowledge:}

Sensory cognition is superficial and simple cognitive principles. The poet's mind is familiar with the shell and the surface of the world. What the poets of the Ghaznavid and Seljuk periods, especially the court poets, see today is a foreign feeling. Things that every eye and ear can comprehend: mountain, tree, rain, garden, sea, green, atmosphere and sound of bird, roar of clouds and wind, etc. What the poet has experienced is a sensory thing and the image that for The expression of this sensory experience is also a sensory and external phenomenon. The poet makes comparisons and expands his experience by using similes. In these verses, for example, Rudaki describes a sensory experience with the help of other sensory matters:

The noble wheel of one made an army, his army was a dark cloud and the wind of Saba Naqib

I saw a lot of light and thunderstorms and I did not see such a terrible thing.

(Rudaki, 1376: 36)

The perception of thunder and lightning in the sky, heavy rain and strong wind is a sensory experience. Rudaki likens the weather to the invasion of the army, and uses the affairs of war (Naqib, oilman, drummer) to expand his sensory experience and give it power and influence.

The sensory image is the product of metaphorical knowledge; metaphorical knowledge is like a simple photograph of nature. In this type of illustration, imagination is not an opportunity to capture an object. (Fotouhi, 1384: 32).

\section{Describe the experience}

The Khorasani style poet describes his sensory perceptions, names them, and seeks many attributes to express his thoughts and experiences. This way of describing experience is influenced by "descriptive imagination" or expressive imagination. The imagery in the poetry of poets of Khorasanian, Azerbaijani, and return styles is of the type of depiction of sensory experience and the poets of these styles use the descriptive imagination more. Images carry senses, and the transmission of the senses of images is more than their emotional burden. For example, see the following Musmat from Manouchehri Damghani:

Crawl and fur that is in autumn is a cool wind from Khorazm Wazan

The horn-shaped tub, from which the branch is weighed, looks like a colored shirt 
As can be seen from the above verses, the poet in the old poetry, after the image he created, sought to describe the experience more than the transmission of sense, and for this reason, in the poetic images of this period, there is a sense of emotion.

Image structures in contemporary poetry

Illustration in contemporary poetry due to various social and philosophical approaches, this poem has different aspects and most of its subject is man and his concerns. The type of images of contemporary poetry can be studied in two axes, vertical and horizontal. The image is created in the horizontal axis with permission, metaphor, simile, etc. In the vertical axis, the images of a poem in relation to each other are examined in a general way and their identity is revealed. The images of contemporary poetry in the vertical axis are deep, moving, and dynamic, and the set of images revolves around a central (-focused) image that is often sensory. The types of images of the horizontal axis of contemporary poetry are recognition (Makniyeh metaphor), simile, metaphor, symbol, irony, atmosphere. Of course, various types of metaphors, metaphors and atmospheres have also been used in the structure of the image, which are widely used in this context (Taheri, 1390: 63)

\section{The most important image structures in contemporary poetry:}

\section{Diagnosis}

"Recognition" literally means "characterization." (Shamisa, 1378: 47). Since personality is a characteristic of man and clarifies his position in the existence of the world. In contemporary poetry, discernment is very effective; But with distinctive features from what has been suggested in classical literature.

The main factor that introduces "discernment" as a component of contemporary poetry is the poets' romantic and symbolic view of existence and related matters. It is with this view that the poet penetrates the universe and blends in with it in such a way that his soul is blown into the soulless body of objects, animals, nature and phenomena, and vivid and dynamic images are created.

In other words, life-giving can be interpreted in such a way that the poet throws the soul of his beautifying artist into ugly or beautiful, living or inanimate elements and creates a new beauty that did not exist before him. Of course, "non-existence" means "non-emergence"; Because "beauty really exists in the world of nature" (Zeif, 1997: 141) and the artist discovers and reveals it. Also by accepting the phrase of Shoghi Zeif that "beauty is an inherent art that arises from two things: nature and the artist. It is the artist who gives beautiful meanings to nature "(Ibid: 140). We must accept that the most satisfying way to create beauty is "discernment"; Because the artist gives nature and objects the main essence of his existence, which is vitality and consciousness, in order to achieve equality.

Of course, "discernment" has also been used in classical literature, but this use has some differences with contemporary poetry, which has led to this poetic fantasy being introduced as a component of contemporary poetry.

The use of human moods, traits, and spirits: In classical literature, common expressions such as "hand of time" are common ... and nature is often depicted on the human face, but in contemporary poetry the least use of Human organs have:

The woman rises from the heart of the earth and presses the tension like a cold towel on the forehead of the earth (Sari, 1387: 26) and instead they have used more of the "characteristics, states and attributes" of man:

The golden bee that plundered the forest and thought that the old honey seller was waiting for his return (Shamloo, 1997: 86). During the studies, only one of the twenty diagnoses was used 
in human organs. Of course, this difference becomes more and more apparent in the path from "Shamloo images" to "images of the seventies onwards". In inclusive images, the human body is still used for diagnosis, and combinations such as "rain on the feet", "air vessels" and "palm of the hand" are encountered, but in images from the seventies onwards, the use of The human organs are much smaller.

\section{Space building}

Space is a poetic creation environment in which imaginary forms are so intertwined that it is not possible to separate them from each other (Ebtehaj, 1389: 94). In contemporary poetry, images are sometimes devoid of similes and metaphors, but with the help of imagined space, they give a very attractive and attractive image to the audience:

Two doves are sitting on the old Sadr branch, which has grown strangely from its peers in the foothills of a strong mountain (Akhavan Sales, 1387: 158).

Or Shamloo says: "There are four prisons here, each prison has two double tunnels, in each tunnel several rooms, in each room several men in prison ..." (Shamloo, 2006: 69).

In the mentioned examples, the image comes to mind, but the illustrator arrays (simile, metaphor, etc.) do not play a direct role, and it is the poetic space that induces the image to the audience.

Exaggeration is a permissible kind by which the poet abandons rational cognition and speaks in such a way that it is not possible in the real world or at least it cannot be understood with material intellect (Shamisa, 1997: 77). If exaggeration is created in accordance with the mind, it is one of the most important forms of poetry for innovation and innovation that provides new spaces for the audience. Like the following two poems:

Your institution is as big as the sky before God creates a star and a sun (Shamloo, 1997: 58).

A window through which the roofs of the world can be seen (Alipour, 1386: 95).

Structural linkage in images, especially in narrative poems

The first feature of the images of contemporary poetry is the continuity of its components in order to better convey the theme of the poem; Not every image is meant to be separate from other images; All images are connected to each other and each is completed next to the other; Unlike the previous poem, which is a poem full of different images and any image can be explored separately from other images. .

Such connection and dependence of images can be seen in many of Nima's poems such as Phoenix, Ghorab, chicken of sorrow, chicken of sculpture, etc.

For example, in the poem "Ghorab", the structure of the images can be expressed as follows:

1- It is sunset and the circle of the sun is filled with sorrow in the yellow veil.

2- A stranger is sitting alone on the beach.

3- Waters are the same color as the sky.

4- The oak tree has turned yellow due to autumn and has fallen on a rock.

5- The black dot is visible from a distance.

6- This is the point of a person who intends to find a place for heartache hidden from the eyes of others. 
7- After the mentioned person finds a place, the stranger stares into his eyes without any anxiety.

8- The stranger sets his eyes on the road to hear the news of happiness or torment

9- Gharab sees only burnt and cloudy foundations (certainly black clouds) on the deserted beach.

10- The solitary and strange people stare into each other's eyes

11- The solitary person says to himself: The stranger is the cause of sorrow, he is ugly, he sits to add to the sorrow of others, he destroys the head of thought.

12- The chosen one cries out to the stranger.

13- Gharab does not pay attention and is sitting motionless

14- Wavy waves come and go ..

15- Man and stranger chew something) Rak, Nima, 1375: 224

The descriptive structure of this poem is very precise as a fictional space. Ghorab, which is reminiscent of ominous, along with the time of sunset that leads to night, autumn, broken oak, etc. have shown a sad and fragile atmosphere, even the waves are gloomy, the poet describes instead of specifying. The components of this image and description are so intertwined. That each is dependent on the other and without it is incomplete. If we consider his family as Nima, the depth of this image and the description of the allegory is implicit, which has been expanded throughout the text (Rak, Pournamdarian, 1998: 121-122

Accuracy in details

Another feature of the images of contemporary poetry is the attention to detail. He leaves nothing to chance, especially those that are more involved in inducing concepts. For example, "Nima's description of the details is so precise that it can be said that Persian poetry has not contained such tangible objects." (Braheni, 1383: 39). For example, in Manley's poem, all the components of the story are described: inner whispers and conversations, the space of the story, the man's movement on the water, etc. For example, when a mermaid talks to Manley, the poet describes the whole space:

The helpless man said nothing to her

A bunch of birds

They patrolled over him and walked away

It was like burning a candle

On top of the ship, the ship comes closer to them (Nima, 1375: 357).

Karshab's foot is not another completely descriptive and visual poem. The poet paints all the scenes. Here, Nima is dealing with the viewer instead of the singer. He tries to show all the contents of the text to the reader with the most detailed details.

Pay attention to time and place

Another feature of contemporary poetry images is attention to place and especially time. Time and place play a decisive role in inducing the concepts and themes of his poems. For example, Nima has been extremely careful in the use of time and space. He believes: "The main material and producer of the author's ideas depends on time and place. Someone who likes my practice 
should say: The author needs to find the material manifestations of his thoughts in their time and place and give them color, clarity and effect, and point to the issues and according to the association of meanings in the minds of the readers. Did not create itself "(Shafi'i Kadkani, 1345: 311)

For example, in Mahtab's poem, "the poet chose the time of dawn because, like dawn, which is the border between darkness and light in the morning, the poet's soul is hesitant in the purgatory between despair and hope" (Pournamdarian, 1998: 330).

Worried, Sahar is standing with me

Morning Wants Me

Happy goat, I bring this dead people, but the news

In the liver, however, thorns

It breaks me through this journey (Nima, 1375: 444.)

\section{Emotional}

In classical poetry, sensuality serves as an idea to unite the elements of human existence and is a definition of the deep connection between these elements. The poet expresses thought in the form of different senses, and in this way shares a kind of unity in the perception of the truth of existence. But contemporary poetry poets use sensuality to create newer spaces; Poems that may not have the sensuality of a classical poet, but are undoubtedly more original in terms of form and poetic boldness: "I drank your voice." This poetic experience is no longer in the dream of unity, plurality, philosophy and mysticism, but speaks of the innocent thirst that is quenched by the voice and is a romantic feeling mixed with innovation that pays more attention to creativity than thought and is able to establish a relationship with an audience that It is familiar with such atmospheres; Without the need for serious thought and thinking. In fact, in order to understand emotionally in contemporary poetry, we need not the interaction of thought and reading or writing, but mental and prior acquaintance with such poetic structures. It is obvious that in the perception of such poetic moments, in contrast to the sensibilities in classical poetry, there is always a kind of complex ambiguity in simplicity that increases the pleasure of the text. For example, the audience's inference from "bitter tears" depends on their personal perception of the concept of "bitter": it can infer from this combination despair, grief, sorrow, infidelity, etc., or all of that. Find the concepts in the sense of "separation". One of the important components of sensuality in contemporary poetry is the ambiguity that gives the poem its face and enjoys it. Also, it ties the space of poetry with a literary array to the aesthetic principle in poetry. : "Then it becomes safe from your voice" (Shamloo, 1997: 262). The integration of visual and auditory senses creates a space in poetry that occupies newer realms of the mind.

Image and description in contemporary poetry

A little reflection and realization in contemporary poetry, we find that this poet expresses that poetry must describe. And Nima believes that "ancient poetry" did not have such a characteristic or that it was far from the description that Nima meant. And he points out that "our poetry [should] be descriptive of all events in the weighted form and in the interior like prose" (Tahabaz, 1989: 82). Because, in his opinion, the basis and purpose of art is image and description. "In the world of art, knowing alone is not enough; It is not enough for man to be aware of something, he wants to show and depict art "(Ibid: 313). And if he succeeds in this goal, art has reached perfection, Nima repeatedly reminds this feature of art: "Art is in pretending and bringing to the screen, by strengthening what people have seen. Bringing to mind things that people have not seen or ignored. The artist should be fair and ask himself: what was the need to say and what does this poem, which wants to put his name on the tongues, give to people who did not have it themselves? 
That is, if the poet can show well and describe well, he has seen in a way that others have not seen, and this view of the poet has given something new to the people. As a contemporary poet, Nima considers the signs of modern literature in such an approach. In his view, not only the reversal of the lines or the change in the rhyme of the poem is a sign of change in literature, but "our literature must change in every way." A new subject is not enough, nor is it enough to develop a theme, to express it in a new way, nor is it enough to start a new form by moving the rhyme back and forth and increasing and decreasing the shutters or other means. The main thing is to change the way we work and give poetry the descriptive and narrative model that is in the world of intelligent people (a point that no one has yet realized, and perhaps the Persians who are new examples of our poetry). They will not understand these soon) until this is done, no correction will take place, there is no wide field ahead. "(Tahabaz, 2016: 65).

As it turns out, Nima is the basic principle of the evolution and modernity of the new poetry, which makes it different from the previous poetry; He knows this "descriptive and narrative" feature and believes that if such a principle is observed, there will be a change. Nima considers himself the first person to create such a descriptive and narrative state in Persian poetry: "In all our ancient poems, it is an artificial state that, due to its subjugation and connection with music, has found this state that every time a poem Apart from formatting our order, we see that it has another effect. I have done this by taking Persian poetry out of this horrible confinement, throwing it into my natural canal, and giving it a descriptive form. I soon realized this from the beginning of my youth when I was a poet. "(Ibid: 62) In any case, Nima has benefited from one of the most obvious principles of art, namely, " image instead of specification "(Hamidian, 1831: 211).

Hamidian says in another book of Dastardisi story: "In general, one of the most important services of Nima to modern poetry was to restore the richness of the image that had diminished around the constitutional era to poetry" (Ibid: 250). It should be noted that Nima's illustration is unprecedented in Persian poetry and is not of the pre-constitutional type of illustration; This is an accepted principle that rhetorical industries such as similes, metaphors, etc. are the basis of illustration, but it should be noted that the characteristics of the images that entered Persian poetry with Nima are fundamentally very different from the imagery in our previous poems.

Classification of images in contemporary poetry based on literary criticism approaches

Two types of imagery are used in the literature.

1. Linguistic image (real): The poet and writer who uses real language and dictionary to convey a visual image (a natural image of objects) to the mind of the reader has engaged in illustration. Some critics say that using real language to create or represent a sensory experience is called imagery. Realistic writers use this type of imagery to represent reality. (Fotouhi: 2006, 46)

The (real) linguistic image is the theme of the realist storyteller / poet. The language of the story / poem should sense the reader's perception at the level of qualities and put him in close and tangible contact with reality and life. If the words of the story are realistically abstract. The story distances itself from life and is no longer a fictional reality. The realist writer must use visual and sensory words in such a way that the reader sees, touches, smells, smells, hears, tastes, feels the objects as they are. (Fotouhi: $2006: 50$ ). The following are examples of it in contemporary poetry:

He got up to cover

On the child who was sleeping there (the wind was coming).

The hand kicked this one:

$\gg \mathrm{Oh} \ll$ 
The other three woke up, moving

"Water"

He was thirsty and woke up (Akhavan Sales, 2007: 162).

In these verses of contemporary poetry, the word "ah" is associated with the linguistic image and evokes pain in the mind of the reader. Also in the following verses:

\section{"Oops,}

Hey, black! who are you?

]Oh you!"

The narrator said: Their shadow, but what answer can it give?

»ه.

] هـ... O Dad "(Ibid: 164)

The words "i and i" denote the voice and image of someone who shouts and informs someone.

Sometimes the image is at the service of something else, and sometimes it is an independent phenomenon that has value in itself. Based on this, two types of images can be distinguished.

\section{Positive image}

It is born of a sensory perception and the product of a rational thought. The intellect tries to create a formal connection and a slight interest between the similar and the similar. The meaning of the words of this type of image does not exceed the literal meanings and is at the level of apparent and approximate meaning or only in tThe description stops and the expression stops. The dimensions of this type of image are small and its meaning is clear. Because it represents a clear sensory experience with limited dimensions. The origin of this type of image is similarity, symmetry, and similarity between sensory matters. In the positive image, the world outside the world inside the artist is separate. The poet sets an equation between the two sides of the image to prove an attitude or problem. An image is a function of a well-known relationship between two parts. (Futuhi: 1385: 58).

Examples of positive images in contemporary poetry:

I'm afraid I can not sew my lucky shirt

The sun that has sewn a hundred needles on gold (Behbahani, 1998: 199)

My bed / empty oyster is a loneliness / and you are like a pearl / someone else's necklace ... (Ebtehaj, 1378: 102). In these two pieces of contemporary poetry, the poet seeks to create a connection between similar and similar by creating a proof between it.

Extroversion and introversion in the image also creates two types of images:

\section{Surface image}

The most common and simplest imaginary form is resemblance, especially the resemblance of one sensory object to another sensory object. Such images are two-dimensional (like ice crystals) and are easily understood, and at the level of language and sensory communication between words, they stop. . (فتوحى ؛: 1385 (6xamples of surface image in contemporary poetry: 
The window is open / The sky is visible, the roof is facing / Now the man is awake from sleep and his heart is awake / He opens the dove dormitory door / And then the colorful and instructive God, on the vast roofless ornament / "Swallow swarm swarm swan" Readers / with pride and joy, they spread their skirts / they are full of joy in the morning (Akhavan Sales, 2006: $133)$.

The poet's video network in this section does not cause any ambiguity for the reader. This image is a surface narrative of the presence of a man with his pigeons on the roof that the poet sees from the open window of his room. This is the image that Forough Farrokhzad paints of his childhood games:

"I hang earrings on my ears / from two twin red cherries / and I stick dahlia leaves on my nails" (Farrokhzad: 1379: 303). In positive images, the poet seeks his opinion and attitude and creates images in this direction. And since the goal is to prove, "his images must be far from imagination, emotion and exaggeration, and that means a perfectly sensual image that can be visualized, so that such images are perfectly clear, in line with rational and generally accepted standards. And it can be said that in this kind of images, the poet somehow seeks equivalence to prove his attitude and belief "(Delbari, 1394: 81)

\section{Composite image}

It emerges from the connection and integration of simple images and recreates a larger and more complex reality. The logic and method of this combination is part of the imagination and artistic creativity that depends on the mental power and skill of the artist. Composite images are based on and in relation to the message and judgment of the overall aesthetic effect and have an organic connection with it. Examples of composite images include a part of a symphony, a screenplay of a play, a chapter of a novel, a part of a poem or a sequence of a movie (Omid: 1989, 230).

The night sat on the frosted glass / It sat quietly, like a feverish ash / The wind turned the shadows upside down in the yard every breath / The smoky lotus screw rippled on the wall / Among the pines The wizard of the moonlight / He crawled slowly with his bright light / as if he was searching for his wandering soul in the spirit of darkness (Farrokhzad, 1379: 85).

In this piece of contemporary poetry, the poet has created an image composed of: fiberglass, feverish ash, wind, lotus screws, pines, lights, etc., with composition and image.

\section{Conclusion}

If we accept that the image of any kind of perception of the poet from his surroundings and its presentation is through similes, metaphors, etc., whether this perception is sensory or abstract. A study of Persian literary works, especially in the field of poetry, shows that the quality and type of images in the past and present Persian poetry are very different. In the past Persian poetry, the image was used as decoration and remained in only two areas: explaining and emphasizing its meaning and makeup and decorating it, and the poet used them more for sensory knowledge and describing experience, but poetry Today, in the field of imagery, there are features that such features are less seen in classical Persian poetry. In contemporary poetry, the image induces meaning and the meaning is not something separate from the image. Addressing people's situations, structural connection of simplicity images, etc. are the features of contemporary poetry images. In addition to these structural structures, the image is also different in the classical and contemporary periods. In ancient poetry, images are made based on literary arrays such as: simile and metaphor, while the structural structures of contemporary poetry are diverse and based on elements such as: recognition, atmosphere, sensuality and exaggeration, and the image is based on linguistic position to different types. Such as: linguistic image, deep, superficial, compound and positive can be divided. 


\section{References}

Ebtehaj, Houshang. (1999), Rahi va Ahi, Tehran, Sokhan.

Akhavan Sales, Mehdi. (2007) "Man and Composite", from this Avesta, in Mohammad Haghoughi, Tehran, Negah.

Omid, Javad, 1813, Image and Image Making in Art, Chista, No. 62, Pages (219-237)

Anousheh, Hassan (1997), Persian Literary Dictionary, Volume II, Printing and Publishing Organization, Tehran

Braheni, Reza (2004), Gold in Copper, Book of Time, Tehran.

Behbahani, Simin (1998), Footprints to Freedom, Niloufar, Tehran.

Pornography. Taghi (1998), My house is cloudy, first edition, Soroush, Tehran.

. Saeed (2002), The Story of Transformation, First Edition, Niloufar Publications, Tehran.

Khozan, Maryam. (1374), "An explanation of the image in the new critique", Khavaran Monthly, No. 23, pp. (49-61).

Dad, Sima, (2004), Dictionary of Literary Terms, Morvarid, Tehran

Rudaki, Abu Abdullah Ja'far ibn Muhammad. (1376), Diwan, by the effort of ManouchehDaneshpajooh, Toos, Tehran.

Shamloo, Ahmad (1997), Collection of Works, Poems, Look, Tehran.

Shafi'i Kadkani Mohammad Reza, (1345), Mach Ola, third year, p.6.

Shamisa, Sirus. (1997), Expression and Meanings, Third Edition, Ferdowsi, Tehran.

Shamisa, Sirus. (1999), A Look at Sepehri, Contemporary Voice, Tehran.

Tahabaz, Sirus. (1997), On Poetry and Poetry, Daftar-e Zamaneh Publications, Tehran.

Taheri, Hamid (2011), "Image in White Poetry", Contemporary Persian Literature, No. 2, pp: (57-88)

Alipour, Mustafa (2007), Rain of Burnt Grapes, Teka, Tehran

Fotuhi, Mahmoud (2002), "Imagination", Journal of the Faculty of Literature and Humanities, University of Tabriz, No. 185, Year 45, pp. (13-32)

Fotuhi, Mahmoud (2002), "Classical Image", Art Quarterly, 64, pp. (23-43).

Fotouhi, Mahmoud, (2006), Picture Rhetoric, Sokhan, Tehran

Farrokhzad, Forough. (1379), Poetry Divan, Paul, Tehran.

Farrokhi Sistani, Abul Hassan Ali Ibn Jolgh. (1996), Divan, by Narges Ganji, Javidan, Tehran.

Ferdowsi, Hakim Abolghasem. (2008), Shahnameh, Toos, Mashhad.

Manouchehri, Abul Najm (1992), Divan, by the efforts of Diar Siyaghi, Morvarid, Tehran.

Mirsadeghi, Jamal and Meymant Mirsadeghi, (1997), Elements of story, speech, Tehran.

Yousefi, Ghulam Hussain (1982), Gold Paper, Scientific, Tehran. 
Yoshij, Nima. (1996), collection of poems, by the efforts of Sirus Tahabaz, Negah, Tehran. 